\title{
ПРОБЛЕМА ДОСЛІДЖЕННЯ ТЕОРІЙ СУСПІЛЬНОГО ДОГОВОРУ У ВІТЧИЗНЯНІй ФІЛОСОФСЬКІЙ ТРАДИЦІї
}

\section{Н.С. Литвиненко}

Розглядаючи стан дослідження теорій суспільного договору (як класичних, так і сучасних), маємо перш за все констатувати певний дефіцит праць, в яких ці теорії набули всебічної експлікації у вигляді довершеної системи. Науковці, які займалися і продовжують займатися їх аналізом на вітчизняному філософському грунті, виявляють тенденцію до розгляду теорій суспільного договору в загальному контексті вивчення філософського доробку того чи іншого їх автора, або ж схиляються до висвітлення означених теорій в якості етичних чи політичних концепцій справедливості. Якщо перший з наведених підходів є більш характерним для розгляду класичних теорій суспільного договору, то другий підхід вочевидь притаманний аналізу їх сучасних варіантів. Така постановка питання стосовно вивчення суспільного договору, наявна на вітчизняному терені, значною мірою відрізняється від розгляду цієї проблеми в англомовній науковій літературі, де простежується протилежна вітчизняній тенденція до класифікації як класичних, так і сучасних договірних концепцій, а також зведення всіх існуючих їх варіантів до єдиної системи. На відміну від цього, характерною рисою вивчення проблеми суспільного договору у вітчизняній літературі є порівняльний аналіз концепцій, розвинутих протягом того чи іншого проміжку часу, що особливо притаманно розгляду класичних теорій, розвинутих упродовж XVII-XVIII ст.

Переходячи до більш детального висвітлення стану вивчення проблеми суспільного договору на вітчизняному філософському грунті,

Актуальні проблеми духовності 
слід також відзначити певний брак уваги, що його завжди зазнавала і до певної міри продовжує зазнавати означена проблема. На наш погляд, такий брак уваги певною мірою не відповідає тому значенню, яке ідея суспільного договору набула в розвитку європейської суспільно-політичної традиції. Безперечно, можна погодитися з думкою більшості дослідників, що з розвитком історичної школи права, еволюціонізму та позитивізму, теорії суспільного договору певною мірою втрачають свою наукову вагу як механізм обгрунтування виникнення держави і громадянського суспільства, проте, вони видаються цілком здатними і в теперішній час надати позитивного імпульсу розвитку таких актуальних політичних концепцій як лібералізм та лібертаризм. В будь-якому з її модифікованих варіантів доктрина суспільного договору завжди мала на меті, з одного боку, пояснити історичне походження політичної влади, держави та суспільства взагалі, а з іншого - характер відносин суспільства і держави, а також сутність їх взаємних зобов'язань [24, с. 22]. Перша сторона вчення зазвичай відхиляється переважною більшістю дослідників як така, що не відповідає історичним фактам, або ж вона витлумачується лише як максимально узагальнене філософське обгрунтування виникнення держави. Проте, як зазначає Медушевський, беззаперечного значення набуває інша сторона, адже добровільно прийняті політичні зобов'язання завжди мають договірну природу. В громадянському суспільстві людина усвідомлює свою приналежність до соціальної організації, яка в обмін на безпеку, захист і можливість самореалізації вимагає від громадянина підкорення владі і лояльності до законів. Отже, права та обов'язки громадян і держави мають обопільний характер, а визнання цієї обопільності і взаємної вигоди становить відношення, що аналогічно можна назвати суспільним договором [24, с. 22].

Теоретична модель суспільного договору уособлює відносини громадянського суспільства і держави, протиріччя, які виникають між ними, а також спосіб вирішення цих протиріч. Саме тому стан найповнішого розвитку означеної доктрини припадає на епоху Нового часу, переддень Французької революції, яка надала можливість здійснення докорінної соціальної трансформації, що сприяло виникненню нового суспільства. Тому, за твердженням Медушевського, можна визнати

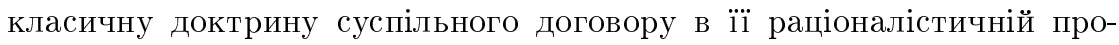
світницькій трактовці в тій чи іншій мірі джерелом всіх значних політичних теорій XIX-XX ст., які ставили своїм завданням не тільки пояснити, а й змінити існуючий світ. Етична передумова суспільного буття, внесена до концепції суспільного договору Кантом, стала фун- 
даментом перебудови суспільства на засадах лібералізму та демократії $[24$, с. $22-23]$.

Серед радянських дослідників філософського доробку класичних теоретиків суспільного договору можна відзначити I.С.Нарського, який розглядає означену доктрину в своїх монографіях по філософії Локка та Канта ([29], [30]). Нарський провадить грунтовний аналіз теорії суспільного договору Локка, порівнюючи її з Гоббсовою в аспектах розподілу верховної влади, політичної форми правління, переходу від природного до суспільного стану, а також характеристик носія верховної влади. Зокрема, Нарський звертає увагу на те, що, якщо Гоббс у вченні про «Левіафан» надає теоретичної форми компромісу між монархією як політичною формою та наявним економічним життям, Локк обгрунтовує компроміс між монархією та республікою в межах самої політики, визнаючи своїм політичним ідеалом конституційну парламентарну монархію поєднану з принципом розподілу влади [28, с. 80]. Розглядаючи вчення Канта, Нарський наводить паралелі 3 аналогічними вченнями Руссо та Гоббса в питаннях, що стосуються народного суверенітету та підкорення верховній владі [30, с. 165].

Відомим є також історико-філософський нарис В.Ф.Асмуса, що досліджує концепцію суспільного договору побудовану Руссо [4]. В даному випадку цікавим є те, що, порівнюючи вчення Руссо та Гоббса, Асмус відзначає протилежність між ними не в загальних термінах абсолютизму та демократії, а саме в трактовці природи індивіда, який, на відміну від Гоббса, визнається Руссо здатним до співчуття [4, с.95]. З цього приводу доречною видається точка зору А.Н. Медушевського, який стверджує, що при більш детальному розгляді концепції Руссо та Гоббса зовсім не виявляються настільки протилежними, як це прийнято вважати. На його думку, Руссо, як і Гоббс, розпочавши 3 індивідуалістичної природи людини, прийшов насамкінець до апології суспільного, колективного начала, що знайшло свій вираз у тиранічній владі більшості над меншістю. Саме тому, вважає Медушевський, вчення Руссо має так багато спільного із здавалося б протилежною доктриною Гоббса [24, с. 11].

В даному контексті слід також згадати монографію Г.А. Заіченка, що досліджує серед інших вчення про суспільство та державу Локка [14]. Вона відзначається не тільки грунтовним аналізом зроблених Локком висновків, а також демонструє суперечності, що існують в інтерпретації філософії Локка, виявляючи їх причини і простежуючи у зв'язку з цим еволюцію його поглядів.

Порівнюючи концепції Локка, Гоббса та Спінози, Заіченко вказує 
на спільне для них уявлення про індивіда як носія унікальної, незмінної та вічної природи, що, на його думку, є свідченням їх антиісторизму [14, с. 163]. В ході проведеного в монографії порівняльного аналізу виявляється і низка відмінних рис притаманних теоріям Локка та Гоббса. Це, зокрема, різне розуміння класиками поняття «природного права» i, що становить найголовнішу відмінність між ними, різні підходи до вирішення питання про розподіл влади. Обгрунтовуючи принцип розподілу влади, Локк відкидає таку найбільш прийнятну, з Гоббсової точки зору, форму правління як абсолютна монархія, при цьому визнаючи існування «помірних монархій», побудованих на засадах відстоюваного ним принципу [14, с. 167].

В трактовці поглядів Канта та інтерпретації його теорії суспільного договору також відмічається існування певних розбіжностей у поглядах. В той час як В.Н.Кузнєцов говорить про «категоричне непогодження» Канта 3 «позначеною рисами тоталітаризму» концепцією Гоббса, згідно якій за умов договірного створення держави індивіди втрачають свободу, притаманну їм в природному стані і делегують усі свої права голові держави [23, с. 26-27], В.В. Дутчак зазначає, що Кант відкидав право підданих на повстання, таким чином наближаючи концепцію Канта до Гоббсових висновків [13, с. 83]. В свою чергу А. Коваленко, досліджуючи теорію Гоббса, зауважує на те, що перехід до суспільного стану позначається не відмовою від свободи взагалі, а лише відмовою від «розгнузданої свободи» [19, с.66], у такий спосіб протиставляючи свій погляд твердженню Кузнєцова.

У російській та українській науковій літературі класичні теорії суспільного договору нерідко аналізуються в контексті розробки концепції громадянського суспільства. 3 цього приводу слід відзначити дослідження К.С. Гаджиєва, І.А. Гобозова та Л.А. Халаєвої. Зокрема роботи Гаджиєва відзначаються ретельним порівняльним аналізом понять громадянського суспільства, держави та свободи, які використовують в своїх працях Локк, Руссо та Кант. Зокрема він вказує на взаємозамінність понять «громадянське суспільство» i «держава»в концепціях вищезгаданих класиків суспільного договору [9, с. 20]. Цікаво відзначити, що Гаджиєв до певної міри погоджується з Медушевським у тому, що при всьому демократизмі і прихильності Руссо до ідей індивідуальної свободи та рівності, в його міркуваннях неможна не впізнати «зловісні контури» Гоббсового Левіафану [9, с. 20].

Серед інших звертає на себе увагу також дослідження Б.Г. Капустіна [16], який доволі нетипово для вітчизняного вивчення класичних теорій суспільного договору зосереджує увагу на розгляді таких по- 
нять як «мораль» та «політична мораль», аналізуючи в зв'язку з цим концепцію Гоббса. Слід зазначити, що подібний підхід до Гоббсового вчення наближує трактовку Капустіна до інтерпретацій згаданої концепції, характерних для англомовної критичної літератури.

Серед сучасних теорій суспільного договору провідне місце посідає концепція справедливості сформульована Джоном Ролзом. Концепція Ролза вважається домінуючою в царині сучасної політичної філософії саме в тому сенсі, що майже всі наступні теоретики будували власні вчення, протиставляючи свої аргументи висновкам Ролза. Таким чином побудова Ролза являє собою не тільки оригінальну концепцію, що набула певного історичного значення в якості альтернативного інтуїтивізму та утилітаризму етичного вчення, вона також визнається осередком усіх сучасних дискусій про справедливість так само, як і джерелом ідей, розроблених в переважній більшості подальших версій суспільного договору.

Поясненням вагомого значення набутого концепцією Ролза, викладеною ним в «Теорії справедливості» (1971), служить не тільки його повернення до попередньої традиції змістовної, радше ніж семантичної моральної та політичної філософії, а також залучення ним до своєї теорії великої кількості матеріалу суспільних наук, що сприяло популярності Ролзової книги серед найширшої аудиторії. Іншим істотним фактором подібної популярності стало те, що з метою обговорення принципів справедливості, що становлять предмет загальної зацікавленості, в своїй конструкції Ролз використовує модель суспільного договору, яка є широко відомою філософською конструкцією. Висвітлюючи принципи справедливості, які складають фундамент домінуючих моральних та політичних поглядів сьогодення і з'являються внаслідок загально прийнятної процедури вибору, а також характеризують реальний суспільний устрій, Ролз пов'язує власні умовиводи з наявною соціальною, економічною та політичною ситуацією, що таким чином забезпечує визначальне положення його теорії серед інших сучасних версій суспільного договору. Якраз тому саме концепція Ролза завжди привертала і привертає найбільше уваги як іноземних, так і вітчизняних науковців, що також зумовлює її провідне значення для нашого дослідження.

Розробку сучасних варіантів суспільного договору у російській та українській науці можна розглядати за двома періодами. Перший, радянський період, характеризується здебільшого критичним висвітленням означеної доктрини в руслі домінуючої в той час марксистськоленінської ідеології, проте не видається позбавленим низки цікавих 
підходів та висновків, що безперечно заслуговують принагідного розгляду.

Зокрема Л.Г.Грінберг та А.І.Новіков, розглядаючи в своїй книзі проблему соціальної справедливості, вказують на два підходи до їі вирішення, перший з яких, на їхню думку, виражається в спробі перенесення абстрактних принципів справедливості на грунт соціальних відносин і живиться юридичним світоглядом, а другий, що виявився ще в «Економічно-філософських рукописах 1844p.» К. Маркса, характеризується постановкою і вирішенням проблеми соціальної справедливості, виходячи із сутності власне суспільних відносин [11, с. 102]. Природно, що концепцію соціальної справедливості Ролза вони відносять до спроб вирішення згаданої проблеми, що складають перший підхід.

Аналізуючи його висновки, Грінберг та Новіков вказують на Ролзове твердження про можливість наукового осягнення сенсу справедливості, що, на їх погляд, вирізняє Ролза поміж інших іноземних теоретиків, які скептично ставляться до подібної можливості. Проте, сформульовані Ролзом принципи, за твердженням Грінберга та Новікова, жодним чином не являють собою результату наукового дослідження соціальної дійсності, а лише становлять умоглядні уявлення автора про те, що він вважає раціональним у людських взаємовідносинах [11, с.119]. До того ж Грінберг та Новіков піддають сумніву визнаний демократичний характер усіх міркувань Ролза про рівність. Вони звертають особливу увагу на те, що американський філософ виправдовує нерівність у сфері расових та національних відносин, аби вона слугувала інтересам менш захищених рас та народів. У такий спосіб, на думку Грінберга та Новікова, Ролз фактично визнає наявність різних соціальних типів, існування яких зумовлено соціальними групами та класами, що суперечить його намаганням вести розмову про людей як виключно абстрактних та первинно рівних індивідів [11, с. 121].

Загалом в монографії Грінберга та Новікова концепція Ролза набуває доволі критичного висвітлення, однією з причин чого, на їхню думку, виступає зведення ним проблеми соціальної справедливості лише до розподілу благ, залишаючи за межами обговорення питання про справедливість та несправедливість у сфері відносин до засобів виробництва. Це, з огляду авторів монографії, становить вагомий недолік усієї традиції західної соціально-економічної думки, адже, на їх переконання, розподіл благ неможливо зрозуміти з самого себе. Проте, деякі з Ролзових тверджень набувають в інтерпретації Грінберга та Новікова позитивної оцінки: зокрема думка Ролза про необхідність 
забезпечення кожному можливості для прилучення до культури власного суспільства, а також про відношення до природних талантів та здібностей як до суспільного надбання [11, с. 128].

Не менш цікавим дослідженням радянського періоду є також стаття Є.Л. Дубко, в якій теорія суспільного договору Ролза розглядається в контексті одного з напрямків англо-американської етичної думки [12]. Загалом Дубко розрізняє три таких напрямки, які отримують назви аретологічних, «гуманістичних» та імперативних теорій моралі.

Якщо аретологічна етика (Ф. Фут, Дж. Анскомб та ін.) зосереджує увагу на цінності особи та її поведінки і походить від «етики доброчесності» Сократа та Аристотеля, а «гуманістичні» теорії (Є.Фром, П. Куртці, К.Байер та ін.) проголошують своїм ідеалом автентичне життя і автономію суб'єкта, ядро імперативізму, представниками якого є У.Франкена, Р. Брандт, Р. Хеар, а також Дж. Ролз, складає деонтологічна етика. Припускаючи, що мораль може і повинна до певної міри мати особистісне вираження, імперативісти приділяють головну увагу позаособовій «позитивній соціальній моралі» [12, с. 112]. Імперативні теорії моралі являють собою так звану «етику принципу», тобто таку етичну концепцію, яка визнає існування певних правил і принципів сутності моралі. Виходячи з твердження про існування об'єктивної тенденції перевтілення традиційної моралі на рефлексивну та особистісно обмірковану, представники імперативного напрямку проголошують моральну точку зору виключно раціональною. Дубко приділяє окрему увагу розгляду поняття «раціонального суб'єкта». Відзначаючи великий вплив етики Канта на імперативні теорії, які запозичили його ідеї морального закону, зобов'язання та автономії морального суб'єкта, Дубко говорить про виникнення поняття так званого «ноуменального суб'єкта» за рахунок позбавлення від будь-яких емпіричних передумов. Саме в цьому ракурсі Дубко характеризує теорію Ролза, який, за його висловом, надає портрет деіндивідуалізованого агента. Таке узагальнення сприяє створенню образу абстрактного індивіда, соціального і водночас відокремленого від інших. Подібна установка призводить до універсалізованості моральних суджень, що надає змогу аналізувати моральну оцінку у відносно позачасовому стилі [12, с. 113]. На думку Дубко, імперативісти перебільшують здатність моралі до примирення класових протиріч і зображують політику та участь у ній як інтелектуальну та моральну діяльність [12, с. 115].

Серед інших слід також відзначити монографії К.А. Шварцмана та 3.А. Бербешкеної, відомі своїм критичним аналізом договірної концепції Ролза, що провадиться ними в контексті розгляду західних тео- 
рій моралі та концепцій справедливості ([39], [6]). Зокрема Шварцман говорить про утопічний характер концепції Ролза, який виявляється при спробі співвіднесення її з реаліями капіталістичного суспільства [39, с. 171]. В свою чергу Бербешкіна також наголошує на утопічності Ролзової побудови, проте визнаючи за ним висунення низки важливих ідей, таких як твердження про те, що справедливість є засобом пом'якшення та урегулювання існуючої несправедливості, що наявність нерівності сама по собі не становить несправедливості та деяких інших $[6$, c. $71-72]$.

Окремої уваги заслуговує дослідження А.М. Міграняна, який розглядає сучасні теорії суспільного договору, представлені Дж. Ролзом, Р. Нозіком та Р. Дворкіним, в якості ліберальних теорій демократії [26]. Мігранян вважає, що в питаннях рівності та свободи ліберальні теорії демократії виявляють свій обмежений характер, що, на його думку, детерміновано «класовою позицією» їх прибічників [26, с. 125]. 3 цим пов'язана притаманна концепціям антиегалітаристів Нозіка, Хаєка та ін. і проегалітаристів в рамках демократичної теорії Ролза, Дворкіна та ін. спільність методології, яка полягає в тому, що всі згадані теорії зображують абстрактного індивіда в умовах певної гіпотетичної ситуації, а потім розглядають питання про те, які саме цінності він повинен обрати. При цьому у такий спосіб зображений абстрактний індивід фактично позбавлений можливості обрати будь-які цінності, що радикально відрізнялися б від тих, що є вже прийнятими в даному суспільстві. 3 огляду Міграняна, докорінна обмеженість теорій ліберального егалітаризму, до складу яких входять і сучасні теорії суспільного договору, полягає в тому, що хоча первинний розподіл матеріальних благ поміж різними індивідами передбачається рівним, подальші взаємовідносини між ними в сфері розподілу повинні будуватися на засадах законів, що діють в межах вільного ринку. Це означає, що при розробці насправді здійсненої теорії рівності потрібно буде відмовитися від основних елементів ліберальних егалітаристських теорій - нейтральних принципів справедливості і концепції абстрактного раціонального індивіда, який робить вибір між різноманітними цінностями [26, с. 125].

В працях радянського періоду цілої низки інших дослідників також розглядаються антиномії свободи та рівності, рівності та справедливості в західній етичній і соціально-політичній думці. Загалом критичному аналізу піддаються ліберальні та егалітарні уявлення про соціальну рівність на прикладі договірної теорії, відомої також під назвою концепції дистрибутивної справедливості, Р. Нозіка, теорії справедливості Дж. Ролза та ін. ([5], [22], [35], [36]). В цілому можна сказати, що ра- 
дянські дослідники проаналізували нові тенденції в сучасній західній філософії моралі, однак, практично не було видано праць присвячених загальному аналізу сучасного стану західної етики, який виражає специфіку постановки проблем в етиці ХХст., і особливо в його другій половині [21, с. 34].

Видається доречним проаналізувати розгляд сучасних теорій суспільного договору в пострадянський період за двома напрямками, а саме російським та українським. На терені як російської, так і української соціально-філософської думки на сучасному етапі відбуваються спроби поглибленого вивчення версій договірної доктрини, здійснення яких, проте, не позбавлене і певних труднощів. Їх джерелом насамперед виступає стан недостатнього розвитку галузі політичної філософії, саме в контексті якої в англомовній традиції і розглядаються сучасні договірні теорії. Проблема розвитку політичної філософії в сучасній Росії стала основною темою проведеного журналом «Вопросы философии» «круглого столу», обговорення в межах якого сприяло висвітленню не тільки проблем, а й основних напрямків досліджень та перспектив розвитку цієї галузі філософського знання. Зокрема I.I. Кравченко відмічає, що хоча традиція політико-філософського мислення налічує вже більш ніж дві з половиною тисячі років і походить ще із Стародавньої Греції, як самостійна філософська галузь політична філософія конституювалася лише в минулому столітті. Напевно, що досягнення світової політико-філософської думки не залишалися поза колом інтересів більшості вітчизняних дослідників і за радянських часів, проте притаманна цьому періоду політична догматика до певної міри заважала формуванню власних традицій російської політичної філософії [32, с. 4]. Вочевидь саме цей факт і становить причину того, що за радянських часів розгляд сучасних версій договірної доктрини провадився переважно в напрямку етики, що до певної міри детермінує їх вивчення і на сучасному етапі. Як зазначає Капустін стосовно розвитку політичної філософії в сучасній Росії, причинами iii теперішнього «ембріонального або деформованого» стану $є$ відсутність традиції вітчизняної політичної філософії, як вона розуміється на Заході, а також, що є спільним для Заходу і Росії (та вочевидь і для України) є те, що існування політичної філософії в умовах сучасного світу стало проблематичним. Тобто цей світ не сприяє виникненню традиції політико-філософського мислення, якщо вона не зародилася в країні раніше внаслідок особливостей її історії $[32$, с.8].

На наш погляд, в даному випадку варто не погодитись з думкою Капустіна, адже філософська наука не зупиняє свого розвитку 
як в Росії, так і в Україні. Більш прийнятним видається судження Т.О. Алексєєвої про те, що сучасний стан політичної філософії являє собою скоріше кризу очікування. На її думку, за останнє десятиліття політична філософія відчутно змінила свою змістовну орієнтацію. Сьогодні на перший план її досліджень виходять проблеми справедливості, свободи, політичної спільноти [32, с. 15$]$.

Саме Т.О. Алексєєва $є$ найактивнішим дослідником політичної філософії Джона Ролза в Росії. В своїй монографії «Справедливість. Морально-політична філософія Джона Роулса» (1992) вона не тільки робить детальний аналіз та простежує еволюцію Ролзових поглядів, а також розглядає концепцію Ролза окремо в політичному та економічному аспектах, порівнюючи її як із сучасними договірними концепціями Дворкіна та Нозіка, так і з класичними теоріями суспільного договору Локка, Руссо та Канта. В ході своїх роздумів Алексєєва доходить низки цікавих висновків: зокрема вона визнає Ролзові принципи справедливості цілком раціональними i, можливо, навіть ефективними в умовах не лише однієї країни, проте спосіб їх виведення видається їй доволі штучним та не зовсім підходящим для вирішення поставлених Ролзом завдань. Алексєєва також високо оцінює Ролзові твердження про рівність у свободах та розподільну нерівність на користь найменш забезпечених та погоджується з його припущенням про те, що саме політичні інститути повинні зміцнювати, а не руйнувати гідність особистості та її самоповагу. Їй також видається виправданою фіксація з початку політичних та особистих прав, а потім вже прав економічних та соціальних. 3 точки зору Алексєєвої, Ролзова теорія становить необхідний фундамент для побудови нових, не обов'язково ліберальних концепцій $[1$, с. 48-49]. В якості основного недоліку концепції справедливості Ролза Алексєєва вбачає те, що за умов функціонування його дистрибутивної схеми велика кількість громадян (діти, старі, немічні) опиняється за межами справедливості [1, с. 108].

В низці своїх подальших статей Алексєєва аналізує вплив ідей Канта на Ролзову філософію разом із основними напрямками дискусії, спричиненої появою його «Теорії справедливості» [2, с. 31-33].

Ще одним свідченням поступового піднесення російської політичної філософії є дослідження договірної концепції Девіда Готьє, проведене Б.Н. Кашніковим у зв'язку з аналізом проблем і напрямків розвитку лібералізму в сучасній Росії [18]. Кашніков надає концепції Готье характеристики не моральної теорії, яка до певної міри $є$ притаманною усім вищезгаданим сучасним версіям суспільного договору, а теорії раціонального вибору, що є доволі популярною в аналітичній філософії. 
Порівнюючи побудову Готьє з вченням Гоббса, Кашніков доводить, що ключова різниця між ними полягає в тому, що для Гоббса мораль уможливлюється існуванням сильного механізму примусу, в той час як Готьє стверджує, що поводження згідно нормам моралі природно випливає з раціональності учасників кооперації [18, с. 37]. На думку Кашнікова, концепція Готьє не витримує критики в жодному з заторкуваних нею аспектів, як то в аспекті раціональності зображуваних ним індивідів, а також в аспекті загальної «моральності» його теорії. Проте головним недоліком побудови Готьє Кашніков вважає те, що вона не $є$ істинною в прагматичному сенсі слова, тобто не може працювати як концепція загальної справедливості. Єдиною сферою, де у такий спосіб побудована концепція могла б бути застосована, на думку Кашнікова, є етика бізнесу, однак, навіть в цьому випадку подібна етика бізнесу повинна доповнюватися системою нормативних вимог по відношенню до осіб, які залишаються поза межами угоди з загальною системою соціальної відповідальності [18, с. 39-42].

Серед інших російських публікацій з політичної філософії вирізняється також дослідження Р.Г. Апресяна, який торкається концепції Ролза в контексті аналізу поняття суспільної моралі [3]. Розглядаючи в цьому аспекті «Теорію справедливості», Апресян зазначає, що в своїй концепції Ролз реалізує так званий «соціологічний» або «соціологізаторський» підхід в етиці, за якого мораль виводиться з потреб суспільства, характеризується як його функція, елемент суспільної організації та різновид соціальної дисципліни [3, с. 7]. В теорії Ролза суспільна мораль пов'язана з діяльністю інститутів, які розподіляють фундаментальні права та обов'язки. Подібна мораль в контексті Ролзової праці отримує назву «моралі асоціацій», яка може набувати різних форм, проте в складних асоціаціях визначальним регулятором завжди залишаються принципи справедливості [3, с. 10].

У відповідь на публікацію Апресяна Капустін, досліджуючи поняття «суспільної моралі» у власній статті [17], розглядає еволюцію концепції Ролза, зазначаючи, що в своїх більш пізніх працях американський філософ повністю переосмислює ключове поняття справедливості, залишаючи при цьому кантівський апріоризм, і адаптуючи це поняття до «логіки «суспільної моралі» і виводячи з-під «юрисдикції» метафізики моралі» $[17$, с. 3$]$.

В українській науці сучасні версії контрактаріанізму лише нещодавно почали привертати увагу вчених, у зв'язку з чим з'явилася низка публікацій, які досліджують концепцію Джона Ролза та інших теоретиків суспільного договору. Однак поза увагою не залишаються 
й класичні варіанти договірної доктрини, вивчення яких продовжує здійснюватися на вітчизняному філософському терені. Зокрема цікаво відзначити дослідження основних інтерпретацій рівності в межах теорій природного права Гоббса та Локка проведене О. Слободянюк [34]. Демонструючи відмінність підходів у розумінні класиками природного закону, який в Гоббса ототожнюється з інстинктом самозбереження, а в Локка синтезує в собі разом із Гоббсовим самозбереженням також певну моральність, що поєднується з правом приватної власності.

Слободянюк відмічає також факт збігу висновків, зроблених філософами, у питаннях, що стосуються розуміння ними тогочасної політичної реальності, яка в ідеалізованому вигляді складає фундамент ïх політико-філософських конструкцій. Визначаючи поняття соціальної рівності як зумовлене інстинктом самозбереження, Слободянюк приписує Гоббсовій рівності характеристику рівності біологічної, що в свою чергу легітимізує будь-який суспільний лад за умови одностайного підкорення. Локкова ж концепція рівності стосується насамперед сфери майнових відносин і тому видається доволі обмеженою в політичному аспекті, адже не приділяє уваги цій стороні регулювання взаємостосунків індивідів. Загальним висновком дослідження є встановлення номіналістичного характеру концепцій природного права сформульованих Гоббсом та Локком в аспекті визначення ними поняття рівності, яке в обох випадках є одномірним і не передбачає подібної рівності в інших царинах суспільного життя.

Оригінальним є також дослідження Н.Спасенко, яка ставить собі за мету реконструювати політичну філософію Гоббса, при цьому підтвердивши або спростувавши тезу про її взаємозв'язок з іншими розділами Гоббсового вчення [37]. Виконання окресленого завдання Спасенко вважає можливим, зважаючи на аналіз моделей філософського поступу розроблених Куном, Спрейджерсом, Ріделем та Фуко. Дійшовши висновку, що жодна із зазначених моделей не може скласти достатнього фундаменту для реконструкції політико-філософської спадщини Гоббса, Спасенко пропонує розглядати їх як компоненти однієї системи $[37$, с. 59]. Вона також зазначає, що концепція трансформації парадигми Спрейджерса, на відміну від Ріделевої концепції еволюції парадигми, уможливлює розгляд політичної філософії та натурфілософії Гоббса як єдиної цілісності.

Для визначення Гоббсової philosophia prima, тобто вирішення другого завдання поставленого в означеному дослідженні, Спасенко аналізує низку творів філософа, таких як «Elements of Law», «Левіафан» та проект, що дістав назву «Основи філософії», результатом чого стає 
висунення припущення про те, що Гоббсовою philosophia prima $€$ теорія досвіду, межі предметного поля якої збігаються з предметним полем першої частини «Elements of Law» [37, с.67].

3 виходом українських перекладів «Політичного лібералізму» (2000) та «Теорії справедливості» (2001) сформульована Ролзом концепція також набула широкого висвітлення на вітчизняному філософському терені, причому це відноситься як до морально-етичного, так і договірного аспекту його теорії. В даному контексті можна згадати дослідження М.Г. Тура, Л.А.Ситніченко, Л.І. Верецької та С.Г. Мисика, Т.І.Бутченка, О.Г. Коломійця та ін.

Зазначаючи, що теорія справедливості Ролза є осереддям сучасних філософських дискусій про справедливість, Тур простежує розвиток його концепції з двох принципів справедливості як чесності, стверджуваних в «Теорії справедливості» в ліберально-політичну концепцію соціальної справедливості, сформульовану в «Політичному лібералізмі». Тур також відмічає, що, на його думку, деякі з поставлених Ролзом в «Політичному лібералізмі» завдань були ним до певної міри виконані, зокрема йому вдалося вдосконалити аргументи класичної доктрини суспільного договору та протиставити свою концепцію утилітаризму, долаючи його вади. Це виявляється можливим саме тому, що Ролзова угода постає як гіпотетичний експеримент, а не описує історичну реальність, а також спрямована насамперед на захист найменш забезпечених членів суспільства [38, с.43]. Оцінка першого Ролзового принципу справедливості набуває в інтерпретації Тура характеристики абстрактної формули, яка тому у багатьох випадках $є$ одночасно незаперечною і непрактичною.

Порівнюючи теорію Ролза з теорією дискурсу Апеля-Хабермаса, Тур встановлює спільну для них основу, яка полягає в тому, що «їній потенціал легітимаційних імплікацій міститься у формально-процедурній площині». Різниця між ними зводиться до контексту досягнення соціального консенсусу, який в теорії Ролза витікає з наявності факту «глуздового плюралізму», центром якого є справедливість як чесність, а в теорії Апеля-Хабермаса набуває вигляду дискурсивноетичного консенсусу, за яким всезагальна воля знаходить своє вираження в універсальному дискурсі [38, с.56-57]. Порівняння Ролзової конструкції з концепцією П. Рікера, приводить Тура до усвідомлення заперечення ним процедурного формалізму Ролза через обгрунтування розрізнення етики та моралі, а також ствердження примату телеологічного підходу у визначенні ідеї справедливого [38, с. 47].

В своєму дослідженні [33] Ситніченко характеризує механізм су- 
спільного договору як актуальний методологічний принцип сучасної політичної філософії, особливе місце якого визначається не тільки в контексті проблем соціальної справедливості, а й у політичній організації соціального буття та створенні притаманних йому форм урядування. Вона робить спробу визначити роль даного механізму в концепції справедливості Ролза, порівнюючи її з класичними вченнями про суспільний договір Гоббса та Локка з метою з'ясування їх значення та впливу на зміст Ролзових висновків. На думку Ситніченко, саме в політичній антропології вищезгаданих класиків договірної доктрини поняття суспільного договору отримує найповніший розвиток в якості легітимаційного принципу.

В ході проведеного порівняльного аналізу Ситніченко виокремлює низку наступних відмінних рис: в концепції Ролза досягнута домовленість не притаманна даному суспільству й не підтримує його форму правління, а сама набуває форми певних моральних принципів, причому її результатом є не конкретні зобов' язання індивідів, а принципи справедливої організації базисних структур суспільства. До того ж, на відміну від класиків, Ролз, використовуючи механізм суспільного договору, виходить за межі його обмеженої історичної інтерпретації, таким чином усвідомлюючи, на думку Ситніченко, його справжній методологічний та теоретико-легітимаційний сенс. Вона також вказує на певну обмеженість концепції Ролза, яка полягає в розумінні ним справедливості переважно в якості дистрибутивної, тобто розподільної, схеми.

Верецька та Мисик розглядають концепцію Ролза в контексті вивчення категорії справедливості в християнський морально-етичній парадигмі. Вони намагаються дослідити означену категорію шляхом розуміння ¥ї як блага. Розрізняючи суспільне та особистісне тлумачення блага соціалізованого індивіда, науковці відмічають сприйняття справедливості на засадах раціональності, що в свою чергу призводить до розуміння блага як діяння (на противагу його розумінню як наміру). Підвалини блага, на їхню думку, складають позитивна оцінка раціональних дій людини іншими членами спільноти, а також правда, зв'язок з якою уособлює зв'язок із загальнолюдським благом. Ролзове поняття «раціонального плану життя» використовується Верецькою та Мисиком як шлях реалізації дарованій людині свободи вибору, яка змушує її безперервно балансувати на межі справедливості та несправедливості [8, с. 132].

Цікавим також видається дослідження Т.І. Бутченка, який в своїй дисертації прослідковує еволюцію доктрини суспільного договору і виявляє три етапи її розвитку: передкласичний (VXII ст.), класичний 
(VXIII ст.) та посткласичний (II пол. XX ст.) [7]. Бутченко зазначає, що загальним для перших двох етапів $\epsilon$ використання протиставлення природного та громадянського станів, а основною характеристикою третього виявляється встановлення нової нормативної суті договірної концепції і затвердження механізму суспільного договору як форми, спрямованої на визначення принципів справедливості $[7$, c. 6]. Природна межа еволюції договірної концепції окреслюється автором як процедура універсалізації, яка разом з тим становить її логіко-гносеологічну підвалину.

Бутченко також розрізняє декілька тенденщій розвитку договірної концепції в посткласичний період. Перша з них представлена Р. Нозіком, який використовуючи синтез природного права та природного стану, притаманний класичним концепціям суспільного договору, робить спробу легітимізувати ідеал «держави нічного сторожу». Прикладом другої тенденції виступає теорія Р. Дворкіна, яка, на думку Бутченка, являє собою продовження намагання Ролза обгрунтувати ідеал правової та соціальної держави с позицій індивідуалізму. В ході свого дослідження Бутченко визначає, що інтуїтивне осмислення інтеграційної підвалини суспільного буття, виражене концепціями, що складають першу тенденцію, поступається індивідуалістичному варіанту ідеї суспільного договору. Третя тенденція, яку представляє комунікативна теорія Ю. Хабермаса, провадить розробку теоретичних надбань договірної доктрини в напрямку відкриття форм реального консенсусу, а також структурування засад, що сприяють перетворенню індивіда в особистість, здатну до активної участі в ухваленні рішень суспільної значимості. Визнаючи саме цю тенденцію найбільш відповідною практичним реаліям сьогодення, Бутченко разом з тим звертає увагу на її схильність до втрати безпосереднього зв'язку з історичними змінами між приватною та публічною автономією [7, с.9-10].

Як зазначає Бутченко, теоретична розробка проблеми суспільного договору у вітчизняній науці потребує вдосконалення та уточнення. Можна зустріти як випадки недооцінки нормативної ролі сутності договірної концепції, так і приклади поверхового зведення її функції лише до пояснення історичного факту виникнення держави внаслідок певної угоди між громадянами. При характеристиці особливостей договірної доктрини не завжди береться до уваги специфіка її трансформацій в сучасній соціально-політичній філософії [7, с. 11]. Сучасні версії суспільного договору здебільшого аналізуються окремо від загального напрямку договірної традиції та набувають ознак переважно етичної проблематики. Тому в нашому дослідженні доречним видає- 
ться розгляд та аналіз сучасних варіантів доктрини суспільного договору саме як компонентів єдиної системи договірної традиції в багатоманітності її специфічних рис, як успадкованих від класичних теорій, так і набутих її сучасними версіями.

Таким чином розглянувши проблеми дослідження теорій суспільного договору в російській та українській соціально-філософській думці, можна з впевненістю стверджувати той факт, що означена проблематика не полишає кола інтересів сучасних дослідників і набуває ще ширшого висвітлення з розвитком галузі політичної філософії.

Характерною відзнакою вивчення класичної договірної доктрини як за радянських часів, так і на сучасному етапі $є$ розгляд концепцій суспільного договору окремих теоретиків в загальному контексті їх філософського доробку з майже обов'язковим проведенням порівняльного аналізу цих концепцій з метою визначення їх спільних та відмінних рис. Дослідження сучасних варіантів контрактаріанізму зосереджується переважно на концепції справедливості Джона Ролза і часто набуває ознак морально-етичної проблематики, залишаючи поза увагою той факт, що згадана концепція являє собою пряме продовження новочасної договірної традиції і $є$ побудованою на фундаменті, який становить механізм суспільного договору.

Як наслідок подібного підходу до трактовки доктрини контрактаріанізму можна констатувати фактичну відсутність прикладів зведення всіх зазначених ㄲï версій до єдиної довершеної системи, яка б надала змогу не тільки прослідкувати лінії впливу класичних теорій на сучасні конструкції, а також уможливила б виявлення різних традицій в межах власне договірної доктрини. Однак поява окремих досліджень, зокрема таких як дослідження Ситніченко та Бутченка, які відображають спробу комплексного аналізу сучасних договірних концепцій з огляду на їх класичних попередників, безперечно становить підгрунтя не тільки для систематизації теорій суспільного договору, а й для з'ясування напрямків та перспектив їх розвитку на світовому філософському грунті.

\section{1 Бібліографія}

[1] Алексеева Т.А. Справедливость. Морально-политическая философия Джона Роулса. - М.: Наука, 1992.

[2] Алексеева T.А. Джон Роулз и его теория справедливости // Вопросы философии, 1994, № 10.- С. 27-37. 
[3] Апресян Р.Г. Понятие общественной морали (опыт концептуализации) // Вопросы философии. - 2006. - № 5. - С. 3-17.

[4] Асмус В.Ф. Историко-философские этюды. - М.: Мысль, 1984.

[5] Баталов Э.Я. Социальная утопия и утопическое сознание в США. - М.: Наука, 1982.

[6] Бербешкина 3.А. Справедливость как социально-философская категория.-М.: Мысль, 1983.

[7] Бутченко T.I. Еволюція договірної концепції походження держави: соціально-філософський аналіз. Автореферат дис. на здобуття наук. ступеня канд. філ. наук. Запорізьк. держ. ун-тет. - Запоріжжя, 2004.

[8] Верецъка Л., Мисик С. Розуміння справедливості в християнській морально-етичній парадигмі // Філософська думка. 2002. - № 3. - C. 120-133.

[9] Гаджиев К.C. Концепция гражданского общества: идейные истоки и основные вехи формирования // Вопросы философии.1991. 一 № 7. - С. 19-35.

[10] Гобозов И.А., Халаева Л.А. Гражданское общество: сущностные характеристики // Философия и общество. - 2001. - № 2. - С. 5979.

[11] Гринберг Л.Г., Новиков А.И. Критика современных буржуазных концепций справедливости. Л.: Наука, 1977.

[12] Дубко Е.Л. Новейшая англо-американская этика: метафизическая инерция // Вопросы философии. - 1985. - № 4. - С. 111-119.

[13] Дутчак B.В. Лейбніц і Кант - погляд на виникнення та призначення держави // Грані. - 2002. - № 6- С. 79-84.

[14] Заиченко Г.А. Джон Локк. - 2-е изд. доработ. М.: Мысль, 1988.

[15] Капустин Б.Г. Критика политического морализма // Вопросы философии. - 2001. - № 2. - С. 33-55.

[16] Капустин Б.Г. Различия и связь между политической и частной моралью // Вопросы философии. - 2001. - № 9. - С. 3-25. 
[17] Капустин Б.Г. Заметки об «общественной морали» (в связи со статьей Р.Г. Апресяна «Понятие общественной морали». Вопросы философии. 2006. №5) // Вопросы философии. -2006 . - № 12. C. 3-10.

[18] Кашников Б.Н. «Мораль по соглашению» Давида Готиера как теория российского либерализма // Вопросы философии. - 2006. № 4 . - C. 32-43.

[19] Коваленко А. Передчасно «Левіафан» списувати в брухт // Biче. $-2002-$ № 8 . - С. $64-68$.

[20] Коломіець О.Г. Соціально-договірні засади теорії справедливості Джона Ролза // Мультиверсум. Філософський альманах: Зб. наук. праць./ Гол. ред. В.В.Лях. - К.: Укр. центр дух. культури, 2002. - Вип. 29. - С. 70-79.

[21] Критический анализ современной буржуазной философии // Вопросы философии. - 1985. - № 12. - С. 18-35.

[22] Кувалдин В.Б. Американский капитализм и интеллигенция. - М.: Наука, 1984.

[23] Кузнецов В.Н. Философия права Иммануила Канта // Вестник МГУ. Серия 7. Философия. - 1999. - № 3. - С. 14-30.

[24] Медушевский A.H. Демократия и тирания в новое и новейшее время // Вопросы философии. - 1993. - № 10. - С. 3-23.

[25] Мигранян A.M. Проблема справедливости в современной буржуазной политологии // Вопросы философии. - 1984. - №6. - С. 133142.

[26] Мигранян A.M. Кризис теорий демократии на западе // Вопросы философии. - 1986. - № 9- С. 122-132.

[27] Нарский И.С. Западноевропейская философия XVII века. Учебное пособие.- М.: Высшая школа, 1974.

[28] Нарский И.С. Западноевропейская философия XVIII века. Учебное пособие. - М.: Высшая школа, 1975.

[29] Нарский И.С. Философия Джона Локка.-М., 1960. 
[30] Нарский И.С. Кант.-М.: Мысль, 1976.

[31] Новая история стран Европы и Америки. Первый период. Учеб. по спец. «История». /Виноградов В.Н., Гусева Н.М., Зверев А.М. и др.; под ред. Юровской Е.Е. и Кривогуза И.М. - М.: Высшая школа, 1998.

[32] Политическая философия в России. Настоящее и будущее. Материалы «круглого стола», проведенного журналом «Вопросы философии» совместно с факультетом политологии МГИМО и журналом «Полис» // Вопросы философии. - 2002. - № 4- С. 3-30.

[33] Ситніченко Л.А. «Суспільна угода»: метафора чи методологічний принцип сучасної політичної філософії (Дж. Ролз) // Мультиверсум. Філософський альманах: Зб. наук. праць./ Гол. ред. В.В. Лях. - К.: Укр. центр дух. культури, 2005. - Вип. 46.

[34] Слободянюк O. Природність і рівність: специфіка новочасного натуралізму в царині політичної філософії // Sententiae XII. 2005. - № 1. - С. 199-219.

[35] Современные буржуазные теории общественного развития. / АН СССР, ИНИОН; Я.М.Бергер, Л.Н.Верченков, В.А.Чаликова и др.; Отв. ред. Я.М.Бергер; ИНИОН; Ин-т науч. информ. по обществ. наукам. - М.: Наука, 1984.

[36] Социально-политические теории современной буржуазной идеологии: критический анализ. Сб. ст. / АН СССР, Сиб. отд-ние, Инт истории, философии и филологии; Отв. ред. Р.Г. Яновський; Инт истории, философии и филологии. - М.: Наука, 1981.

[37] Спасенко Н. Засновки історико-філософських реконструкцій політичної філософії Томаса Гобса. // Sententiae XII. - 2005. - № 1. C. 54-69.

[38] Тур М.Г. Ідеї справедливості: імплікації легітимації // Філософська думка. - 2005. - № 4. - С. 33-58.

[39] Швариман K.А. Современная буржуазная этика: иллюзии и реальность // Вопросы философии. - 1985. - № 1. - С. 170-171. 